\title{
An investigation on the unevenness, hairiness and friction coefficient properties of cotton-bamboo blended ring-spun yarns
}

\author{
OĞUZ DEMIRYÜREK
}

DOI: $10.35530 / 1 T .069 .03 .1302$

AYÇA KILIÇ

\section{REZUMAT - ABSTRACT}

\section{Studiu asupra proprietăților de uniformitate, pilozitate și coeficient de fricțiune ale firelor filate cu inele din bumbac în amestec cu bambus}

Acest studiu își propune să investigheze proprietățile de fricțiune, precum și alte proprietăți importante ale firelor, cum ar fi neuniformitatea și pilozitatea firelor. În acest scop, s-au obținut fire filate cu inele din: 100\% bumbac, 50\%/50\% bumbac/bambus și $100 \%$ bambus cu cinci coeficienți diferiți de torsiune $\left(\alpha_{e}: 3,5 ; 3,7 ; 4,0 ; 4,2,4,5\right)$ și în patru densități liniare $\left(N_{e} 16 / 1 ; 20 / 1 ; 24 / 1 ; 28 / 1\right)$. Proiectarea generală factorială a fost utilizată pentru analiza datelor. În concluzie, cel mai mare coeficient de frecare și cel mai scăzut nivel de pilozitate au fost obținute pentru amestecurile pure de bambus, iar cele mai ridicate valori ale neuniformității au fost observate în cazul firelor din 100\% bumbac.

Cuvinte-cheie: bumbac, bambus, amestec, coeficient de frecare, neuniformitate, pilozitate

\section{An investigation on the unevenness, hairiness and friction coefficient properties of cotton-bamboo blended ring-spun yarns}

This study aims to investigate the frictional and other important yarn properties such as unevenness and hairiness of cotton/bamboo blended yarns. For this purpose, \%100 cotton, \%50/\%50 cotton/bamboo and \%100 bamboo ring spun yarns were produced in five different twist coefficients $\left(\alpha_{e}: 3.5 ; 3.7 ; 4.0 ; 4.2 ; 4.5\right)$ and in four different linear densities (Ne 16/1; 20/1; 24/1; 28/1). General factorial design was used for analyzing the data. In conclusion, the highest friction coefficient and the lowest hairiness were obtained for the pure bamboo blends; whereas, the highest unevenness values were observed in pure cotton.

Keywords: cotton, bamboo, blending, friction coefficient, unevenness, hairiness

\section{INTRODUCTION}

Regenerated bamboo fibres are preferred for towels, underwear, home textiles and especially in sportswear for its moisture regain, wicking and antibacterial properties. This fibre may be used in pure $(\% 100)$ form or may be blended with cotton or polyester in the market, in general. There are some studies regarding the fibre, yarn and fabric properties of bamboo and bamboo-cotton blends. Ozgen reviewed and discussed the new biodegradable fibres, yarn properties and their applications in textiles [1]. Prakash et al. investigated the effect of blend ratio on the imperfections, tenacity and hairiness of regenerated bamboo/cotton blended yarns [2]. Sekerden also investigated the unevenness and tenacity properties of regenerated bamboo/cotton blends. In both studies, it was found that increasing bamboo content in the blend affected the quality parameters [3]. Li and Yan studied the tensile properties of regenerated bamboo yarn in different tensile speeds [4]. Majumdar investigated the diameter, tensile, evenness and hairiness properties of cottonbamboo blended yarns. They found that hairiness increases with increasing bamboo content in the yarn [5]. Erdumlu and Ozipek (2008) investigated the quality parameters bamboo, viscose, carded and combed ring spun yarns in pure form. They found that fibre and yarn characteristics of bamboo fibre are quite similar to viscose fibre [6]. Koc and Demiryurek investigated the breaking strength properties of polyester-viscose blended open-end rotor yarns [7]. The fabric properties of bamboo blended yarns were also studied in some papers. Hussain et al. investigated the comfort and mechanical properties of polyester/bamboo and polyester/cotton blended knitted fabrics [8]. The tribological performance of modified bamboo fibre in brake composites was studied by $\mathrm{He}$ et al. [9]. They found that heat treatment of bamboo fibres at $140{ }^{\circ} \mathrm{C}$ for 4 hours makes the friction and wear characteristics of brake composite more stable than untreated ones. Kobayashi et al. examined the frictional wear characteristics of the rubber-bamboo fibre composites. Wear characteristics and tensile strength increased in a range that fibre content is lower than $10 \%$ [10]. Ma et al. investigated the friction and wear properties of bamboo (Phyllostachys heterocycla) fibre reinforced materials. Their results show that carbonized bamboo fibre could reduce the specific wear rate and the noise. In addition it provided stable friction coefficient [11]. Kuhm et al. used capstan equation for examining the fabric friction behavior [12].

Yarn friction is a very important characteristic of yarns in addition to the traditional yarn properties. Fibre type, molecular orientation, fibre surface roughness, yarn linear density, yarn twist, spinning method, yarn unevenness and hairiness may affect the frictional property of the yarns. Balci and Sular reviewed the 
friction property in yarns in terms of its importance and measurement methods [13]. Altas and Kadoğlu examined the carded and combed cotton yarn frictional behaviour and other yarn properties [14]. Kilic and Sular, studied the frictional properties of cottontencel (lyocell) blended yarns produced from different spinning systems [15]. Svetnickiene investigated the friction properties of natural fibressuch as flax, bamboo, bamboo with flax, soy, cotton with sea cell yarns. The highest friction coefficient was found for the flax [16]. Gurarda et al. examined the effects of lubricants on the friction properties of sewing threads [17]. Ozcelik Kayseri investigated the frictional properties of $100 \%$ lyocell, modal and viscose yarns. The fibre type and yarn linear density had a significant effect on the frictional and lint shedding properties, however yarn twist was effective only on yarn-to-yarn friction [18].

The structural and physical properties of the blended yarns are important to determine the fabric properties, as expected. In addition to the traditional yarn properties such as unevenness, imperfections and hairiness; frictional property is also important for yarns. Yarns are subjected to the yarn-to-yarn or yarn-to-metal friction during production. In order to avoid rupture during spinning, the friction coefficient of yarns is important in determining the optimum wax application. In literature survey, the traditional yarn characteristics of bamboo-cotton blended yarns were studied and summarized as above. The frictional and wear properties of natural bamboo reinforced composites were also studied. However we could not met a study examining the friction properties of bamboocotton blended yarns. For this purpose, $\% 100$ cotton, $\% 50 / \% 50$ cotton/bamboo and $\% 100$ bamboo ring spun yarns were produced having five different twist coefficients $\left(\alpha_{e}: 3.5,3.7,4.0,4.2,4.5\right)$ in four different linear densities (Ne 16/1, 20/1, 24/1, 28/1). Statistical analysis was carried out and ANOVA tables and regression curves were obtained.

\section{MATERIALS AND METHODS}

In this study, cotton/bamboo slivers were prepared in $0 / 100,50 / 50$ and $100 / 0$ percentages and yarns were spun in different yarn twist factors $\left(\alpha_{e}: 3.5,3.7,4.0\right.$, $4.2,4.5$ ) and yarn linear densities (Ne 16/1, 20/1 $24 / 1,28 / 1)$. The bamboo fibre was produced in Shangai Xupu from China and supplied from Başyazicioglu Tekstil from Turkey. Bamboo fibre was 1.56 dtex in fineness and $38 \mathrm{~mm}$ in length. The microscopic view of bamboo fibre is given in figure 1. The cotton fibre was also supplied from Başyazicioglu Tekstil from Turkey. The fibre type was Urfa St1 and some of the properties of cotton fibre was measured through Premier ART and given in table 1. The microscopic view of cotton fibre is also given in figure 2 . Cotton fibre was processed by Rieter opener B25 and Rieter C51 carding machine whereas Trützchler BOA1600 BM blow room and TC07 carding machine was used for bamboo fibre. The slivers, obtained from both carding machines were blended and drawed

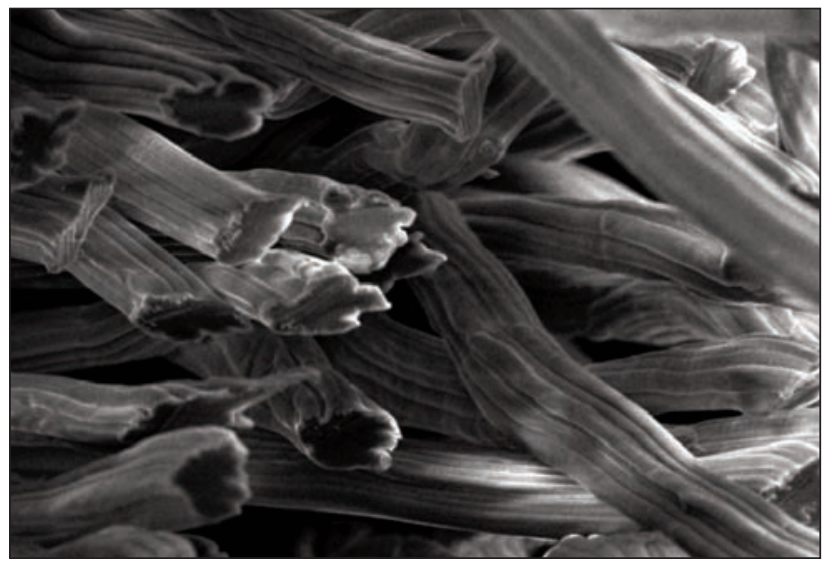

Fig. 1. Microscopic view of bamboo fibre

Table 1

\begin{tabular}{|c|c|}
\hline \multicolumn{2}{|c|}{ COTTON FIBRE PROPERTIES } \\
\hline Property & Value \\
\hline Fineness (mic.) & 4.57 \\
\hline Length (mm) & 29,13 \\
\hline Uniformity index & 85.04 \\
\hline Tenacity (cN/tex) & 30.04 \\
\hline Extension (\%) & 6.72 \\
\hline
\end{tabular}

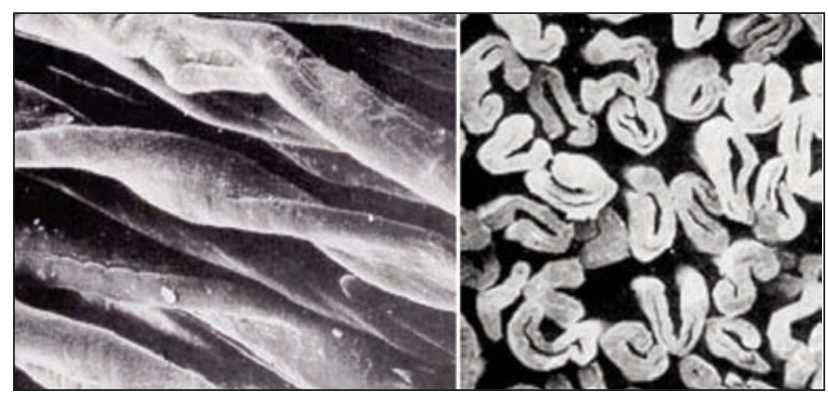

Fig. 2. Microscopic view of cotton fibre

two times in Rieter SB-D10 and the third passage is processed in Rieter SB-D15. The drawing parameters were 8 doubling and 8 drawing ratio in $450 \mathrm{~m} / \mathrm{min}$ speed. Grossenhainer roving frame was used in $1000 \mathrm{rpm}$ spindle speed and rovings were produced in Ne 0.90. Yarns were spun in Shanghai Erfangji Co. sample ring spinning machine having 96 spindles in $14000 \mathrm{rpm}$ spindle speed using $40 \mathrm{~mm}$ ring diameter. Cotton/bamboo yarns were obtained in 0/100, 50/50 and $100 / 0$ percentages. In addition five different twist factors were applied as $\alpha_{e}: 3.5,3.7,4.0,4.2 .4 .5$ and four different yarn linear densities were obtained as $\mathrm{Ne} 16,20,24$ and 28. Total number of cops produced can be calculated by taking the number of blends (3), yarn twist factors (5), yarn linear densities (4) and replication (5) as $3 \times 5 \times 4 \times 5=300$. Yarn linear densities and twist factors of spun yarns were measured for verification through Zweigle L232 and Zweigle D314, respectively. The traditional yarn properties such as unevenness $\left(C V_{m} \%\right)$, imperfections and hairiness 
$(H)$ was measured by Premier PT 7000. Here, $H$ is the length of protruding hairs in $1 \mathrm{~cm}$ yarn [19]. The frictional property of the spun yarns was measured by Zweigle-G 534 which runs according to the Capstan method which measures the yarn-metal friction coefficient. The coefficient of friction is calculated by:

$$
\mu=\frac{\ln \frac{T_{2}}{T_{1}}}{\theta}
$$

Here, $\mu$ is friction coefficient, $T_{1}-$ input tension, $T_{2}-$ output tension and $\theta-$ the contact angle.

Data obtained from the study is analyzed by using general factorial design as a statistical analyzing technique using Design Expert software.

\section{RESULTS AND DISCUSSIONS}

In order to select the best model (linear, quadratic or cubic) in this design, F-test and lack of fit test were applied. The model which gives the highest $R^{2}$ value, least $p$-value can be selected as the best model and can be used for analyzing the data. The normality tests were also conducted. Furthermore, the analysis of variance (ANOVA) table was obtained using the selected model. In those tables, ' $A$ ' represents the cotton ratio in the blend, ' $B$ ' is the yarn linear density in $\mathrm{Ne}$ and ' $\mathrm{C}$ ' is the twist coefficient in $\alpha_{e}$. The confidence interval was determined as $95 \%$. The p-values that is lower than 0.05 were considered as significant in these tables. In addition, the percentage contributions of the terms to the model were demonstrated and the regression curves were introduced. The optimum blend ratio, twist factor and yarn linear density on the response variables [unevenness $\left(\mathrm{CV}_{m} \%\right)$, hairiness $(H)$ and friction coefficient $\mu$ ] of yarns were discussed below, respectively.

\section{Unevenness (CVm\%)}

Mass or weight variation per unit length of yarn is defined as unevenness or irregularity. The coefficient of variation of mass $\left(\mathrm{CV}_{\mathrm{m}} \%\right)$ is one of the calculation methods of variation of mass for the yarns [20] and it is expressed as

$$
C V_{m} \%=\frac{s}{\bar{x}} \cdot 100
$$

where, $s$ is the standard deviation and $\bar{x}-$ the mean of a number of measured estimates of the mass per unit length of the yarn [21].

According to the F-test and lack of fit test, the quadratic model was suggested by the software. ANOVA table using quadratic model was obtained and given in table 2. The $R^{2}$ value is obtained as $90.9 \%$, which indicates that the model explains the $90.9 \%$ of the response variable $\mathrm{CV}_{m} \%$. The model terms havig $p$-values of lower than 0.05 are considered to be significant. The contributions of the terms were also calculated. In the table, the yarn linear density $(B)$ has the highest contribution with $70.61 \%$. The sum of the linear and quadratic effect of the blend ratio $(A)$ is the second in contribution as $17.68 \%$ $(2.63+15.05)$. Other terms have relatively low effect on $C V_{m} \%$. It can be inferred from the table that yarn linear density and blend ratio is the most important factors on $C V_{m} \%$.

The regression curves for $C V_{m} \%$ are given in figure 3 . In these figures, the experimental data is shown as dots or points and the curves are fitted by regression equations. Changing the blend ratio of cotton and bamboo from 0 to 100 can also be seen. In order to see the effect of twist coefficient, $\alpha_{e}=3.5,4.0$ and 4.5

\begin{tabular}{|c|c|c|c|c|c|c|c|}
\hline \multicolumn{7}{|c|}{ ANOVA for CVm\% } \\
\hline Source & $\begin{array}{c}\text { Sum of } \\
\text { squares }\end{array}$ & $\begin{array}{c}\text { Contribution } \\
(\%)\end{array}$ & $\begin{array}{c}\text { Degrees of } \\
\text { freedom }\end{array}$ & $\begin{array}{c}\text { Mean } \\
\text { squares }\end{array}$ & F value & p-value & Significance \\
\hline Model & 309,11 & 90,90 & 9 & 34,35 & 303,12 & $<0.0001$ & Significant \\
\hline A & 8,96 & 2,63 & 1 & 8,96 & 79,05 & $<0.0001$ & Significant \\
\hline B & 240,10 & 70,61 & 1 & 240,10 & 2119,11 & $<0.0001$ & Significant \\
\hline C & 0,53 & 0,16 & 1 & 0,53 & 4,67 & 0.0315 & Significant \\
\hline A $^{2}$ & 51,18 & 15,05 & 1 & 51,18 & 451,72 & $<0.0001$ & Significant \\
\hline $\mathbf{B}^{2}$ & 0,02 & 0,01 & 1 & 0,02 & 0,18 & 0.6732 & \\
\hline $\mathbf{C}^{2}$ & 0,07 & 0,02 & 1 & 0,07 & 0,66 & 0.4173 & \\
\hline AB & 4,33 & 1,27 & 1 & 4,33 & 38,17 & $<0.0001$ & Significant \\
\hline AC & 0,03 & 0,01 & 1 & 0,03 & 0,23 & 0.6328 & \\
\hline BC & 1,03 & 0,30 & 1 & 1,03 & 9,11 & 0.0028 & Significant \\
\hline Residuals & 30,93 & 9,10 & 273 & 0,11 & & & \\
\hline Lack of Fit & 8,12 & 2,39 & 47 & 0,17 & 1,71 & 0.0053 & \\
\hline Error & 22,81 & 6,71 & 226 & 0,10 & & & \\
\hline Corrected total & 340,04 & 100,00 & 282 & & & & \\
\hline
\end{tabular}




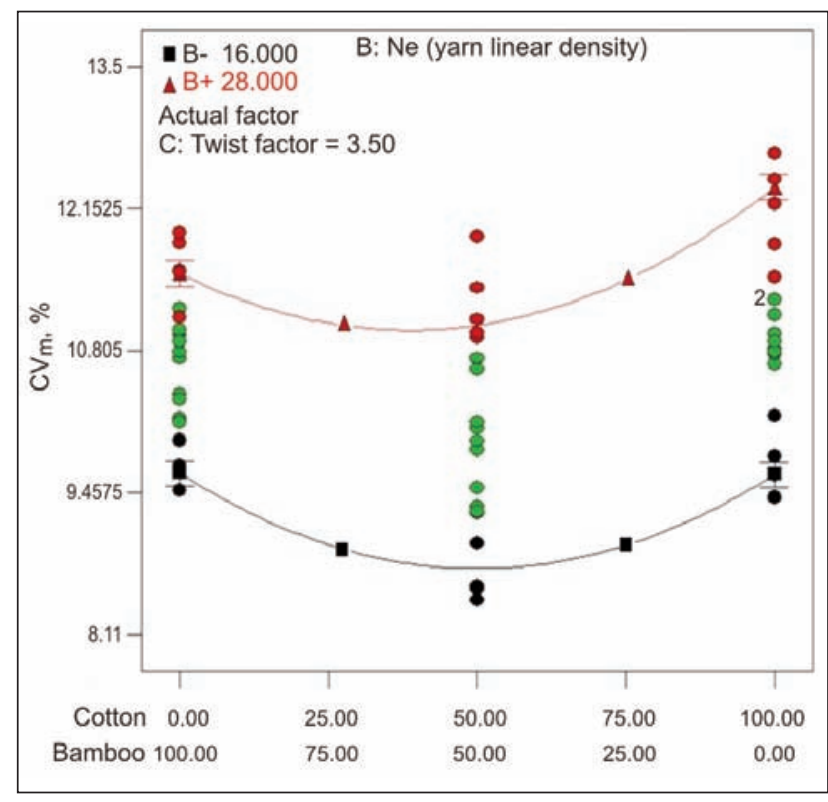

a
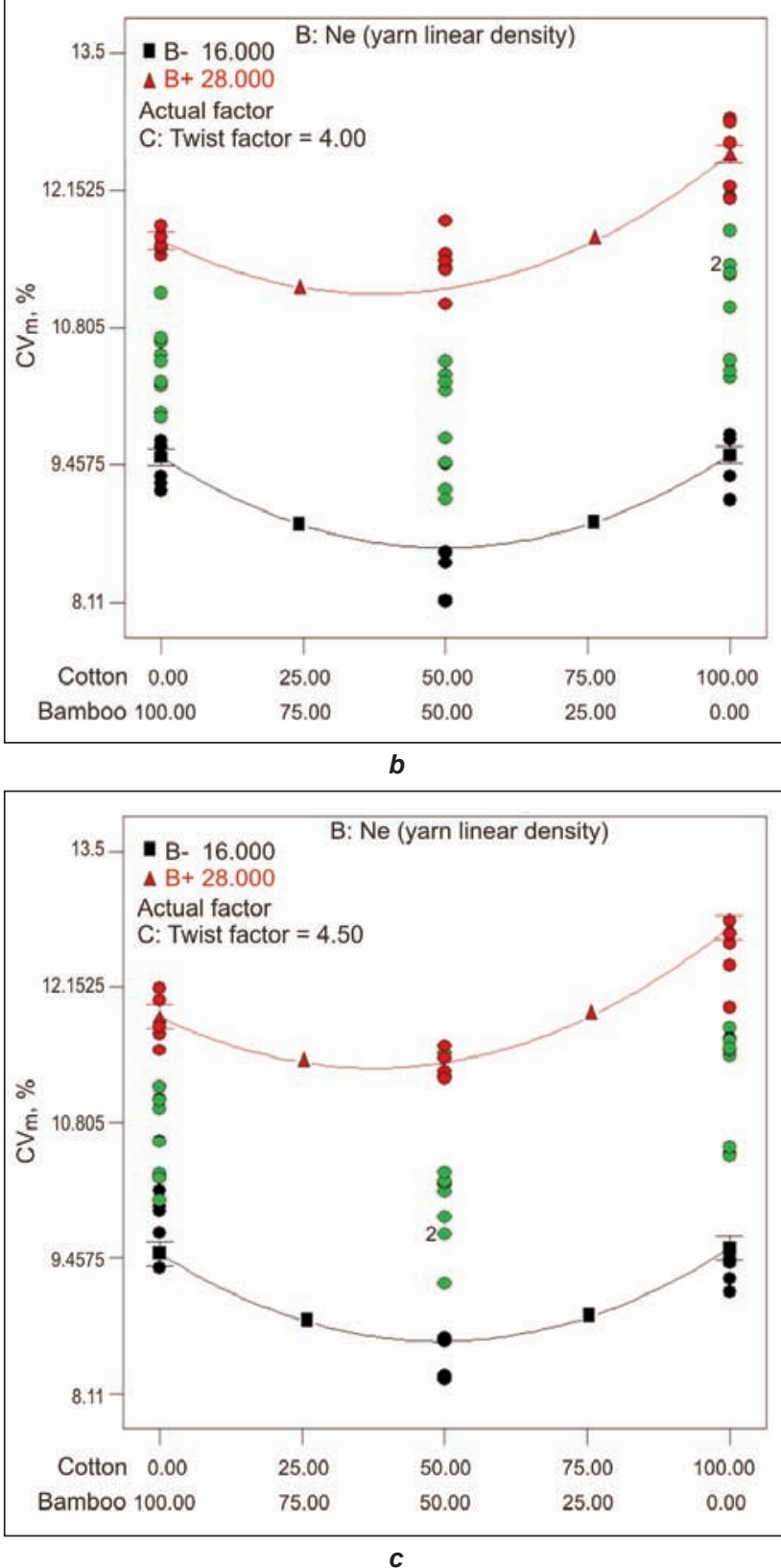

Fig. 3. $\mathrm{CV}_{\mathrm{m}} \%$ for cotton/bamboo blended yarns: $a-\alpha_{e}=3.5 ; b-\alpha_{e}=4.0 ; c-\alpha_{e}=4.5$ was selected and given as figure $3, a, b$, and $c$, respectively. It can be seen that $C V_{m} \%$ is high in finer yarns ( $\mathrm{Ne} \mathrm{28)}$ for each twist levels. This situation may be related to the low number of fibres in the cross section of yarn finer yarns. Increased number of fibres in yarn cross section regulates the imperfections and unevenness regions on the yarn. As the cotton blend ratio in the yarn increases, the $\mathrm{CV}_{m} \%$ decreases up to a certain level and further increasing cotton ratio increases the $C V_{m} \%$. Pure cotton yarns show the maximum $C V_{m} \%$ value. This may be related to the fibre cross sections and fibre-to-fibre cohesion forces in the yarn. The optimum $\mathrm{CV}_{m} \%$ value was seen between $40 \%$ cotton- $60 \%$ bamboo and $50 \%$ cotton $-50 \% 50$ bamboo blend. The cross sections of the fibres were shown in figure 1 and 2. The effective and maximum cohesion forces between curly bamboo fibre and bean-like cotton fibre may be obtained $50 \% / 50 \%$ blend in the yarn. The fibre length variation in cotton fibres is higher than that of bamboo. Thus pure cotton yarns demonstrate high $\mathrm{CV}_{m} \%$ than that of pure bamboo yarns.

\section{Hairiness $(H)$}

Hairiness $(H)$ is defined as the length of protruding hairs per $1 \mathrm{~cm}$ yarn. According to the F-test and lack of fit test, the quadratic model was suggested. ANOVA table using quadratic model was obtained and given in table 3. The $R^{2}$ value is obtained as $65.24 \%$. The model terms having p-values of lower than 0.05 are considered to be significant. The contributions of the terms were also calculated. The maximum contribution is obtained from blend ratio with $57.84 \%$. The second contribution is achieved by twist factor with $4.44 \%$. Other terms have relatively low effect on hairiness. It can be inferred from the table that blend ratio and twist factor are the most important factors on hairiness.

The regression curves for hairiness are given in figure 4. It can be seen that $H$ is high in finer yarns (Ne 28) for each twist levels. The cohesion forces between fibres are low due to the low number of fibres in the cross section of finer yarns, hence the fibres tend to protrude from the yarn hairiness in fine yarns much more than coarse yarns. As the cotton blend ratio in the yarn increases, the hairiness also increases which can be related to the high length and fineness variation of cotton fibres compared to the bamboo fibres. Minimum hairiness was seen in pure bamboo yarns. Increasing the twist decreases the hairiness in the figures, as expected. While increasing the twist, fibre-to-fibre cohesion forces will increase which help to hold the fibre in the yarn body.

\section{Friction coefficient ( $\mu$ )}

According to the F-test and lack of fit test, the quadratic model was suggested. ANOVA table using quadratic model was obtained and given in table 4 . The $R^{2}$ value is obtained as $73.02 \%$. The maximum contribution is obtained from blend ratio with $46.03 \%$ (sum of linear and quadratic effects $A+A^{2}$ ). The sec- 


\begin{tabular}{|c|c|c|c|c|c|c|c|}
\hline \multicolumn{7}{|c|}{ ANOVA for hairiness $(\mathrm{H})$} \\
\hline Source & $\begin{array}{c}\text { Sum of } \\
\text { squares }\end{array}$ & $\begin{array}{c}\text { Contribution } \\
(\%)\end{array}$ & $\begin{array}{c}\text { Degrees of } \\
\text { freedom }\end{array}$ & $\begin{array}{c}\text { Mean } \\
\text { squares }\end{array}$ & F value & p-value & Significance \\
\hline Model & 102,43 & 65,24 & 9 & 11,38 & 56,71 & $<0.0001$ & Significant \\
\hline A & 90,81 & 57,84 & 1 & 90,81 & 452,56 & $<0.0001$ & Significant \\
\hline B & 1,55 & 0,99 & 1 & 1,55 & 7,72 & 0.0059 & Significant \\
\hline C & 6,97 & 4,44 & 1 & 6,97 & 34,74 & $<0.0001$ & Significant \\
\hline A $^{2}$ & 1,35 & 0,86 & 1 & 1,35 & 6,71 & 0.0101 & Significant \\
\hline $\mathbf{B}^{2}$ & 1,62 & 1,03 & 1 & 1,62 & 8,08 & 0.0048 & Significant \\
\hline $\mathbf{C}^{2}$ & 0,07 & 0,04 & 1 & 0,07 & 0,33 & 0.5641 & \\
\hline AB & 0,49 & 0,31 & 1 & 0,49 & 2,45 & 0.1185 & \\
\hline AC & 0,16 & 0,10 & 1 & 0,16 & 0,80 & 0.3722 & \\
\hline BC & 0,16 & 0,10 & 1 & 0,16 & 0,77 & 0.3802 & \\
\hline Residuals & 54,58 & 34,76 & 272 & 0,20 & & & \\
\hline Lack of Fit & 30,63 & 19,51 & 47 & 0,65 & 6,12 & $<0.0001$ & Significant \\
\hline Error & 23,95 & 15,25 & 225 & 0,11 & & & \\
\hline Corrected total & 157,01 & 100,00 & 281 & & & & \\
\hline
\end{tabular}

Table 4

\begin{tabular}{|c|c|c|c|c|c|c|c|}
\hline \multicolumn{7}{|c|}{ ANOVA for friction coefficient $\mu$} \\
\hline Source & $\begin{array}{c}\text { Sum of } \\
\text { squares }\end{array}$ & $\begin{array}{c}\text { Contribution } \\
(\%)\end{array}$ & $\begin{array}{c}\text { Degrees of } \\
\text { freedom }\end{array}$ & $\begin{array}{c}\text { Mean } \\
\text { squares }\end{array}$ & F value & p-value & Significance \\
\hline Model & 0,46 & 73,02 & 9 & 0,05 & 83,74 & $<0.0001$ & Significant \\
\hline A & 0,26 & 41,27 & 1 & 0,26 & 425,88 & $<0.0001$ & Significant \\
\hline B & 0,00 & 0,00 & 1 & 0,00 & 3,51 & 0.0621 & \\
\hline C & 0,04 & 6,35 & 1 & 0,04 & 67,36 & $<0.0001$ & Significant \\
\hline A $^{2}$ & 0,03 & 4,76 & 1 & 0,03 & 53,49 & $<0.0001$ & Significant \\
\hline B $^{2}$ & 0,11 & 17,46 & 1 & 0,11 & 177,74 & $<0.0001$ & Significant \\
\hline C $^{2}$ & 0,01 & 1,59 & 1 & 0,01 & 19,44 & $<0.0001$ & Significant \\
\hline AB & 0,00 & 0,00 & 1 & 0,00 & 0,22 & 0.6362 & \\
\hline AC & 0,00 & 0,00 & 1 & 0,00 & 0,68 & 0.4120 & \\
\hline BC & 0,00 & 0,00 & 1 & 0,00 & 7,32 & 0.0073 & Significant \\
\hline Residuals & 0,17 & 26,98 & 271 & 0,00 & & & \\
\hline Lack of Fit & 0,15 & 23,81 & 47 & 0,00 & 54,27 & $<0.0001$ & Significant \\
\hline Error & 0,01 & 1,59 & 224 & 0,00 & & & \\
\hline Corrected total & 0,63 & 100,00 & 280 & & & & \\
\hline
\end{tabular}

ond contribution is obtained by the quadratic effect of yarn linear density $\left(\mathrm{B}^{2}\right)$ with $17.46 \%$. Twist factor is, contrary to the expectations, the third in importance for the friction coefficient of the yarns with $7.94 \%$ (sum of linear and quadratic effects $C+C^{2}$ ).

The regression curves for friction coefficient $\mu$ are given in figure 5. It can be stated that increasing twist factor increases friction coefficient, as expected (figure 5, $a, b$ and $c$ ). Increasing twist increases the rigidity of the fibre and friction coefficient increases, as well. In figure $5, a$, the finer yarns show higher friction coefficient; whereas in figure $5, b$ and $c$, coarser yarns have higher friction coefficient values than finer yarns. The critical twist coefficient is $\alpha_{e}=3.77$ in which the friction coefficient of finer and coarser yarns are almost equal. Increasing cotton blend in the yarn decreases the friction coefficient. This may be due to the high friction coefficient of bamboo fibre. The natural bamboo fibre are already can be used in brake composites and it is used for its improved wear characteristics [9-11]. Hence the increasing bamboo blend in the yarn increases the friction coefficient.

\section{CONCLUSIONS}

In this study, unevenness, hairiness and the frictional properties of cotton/bamboo blended yarns are 

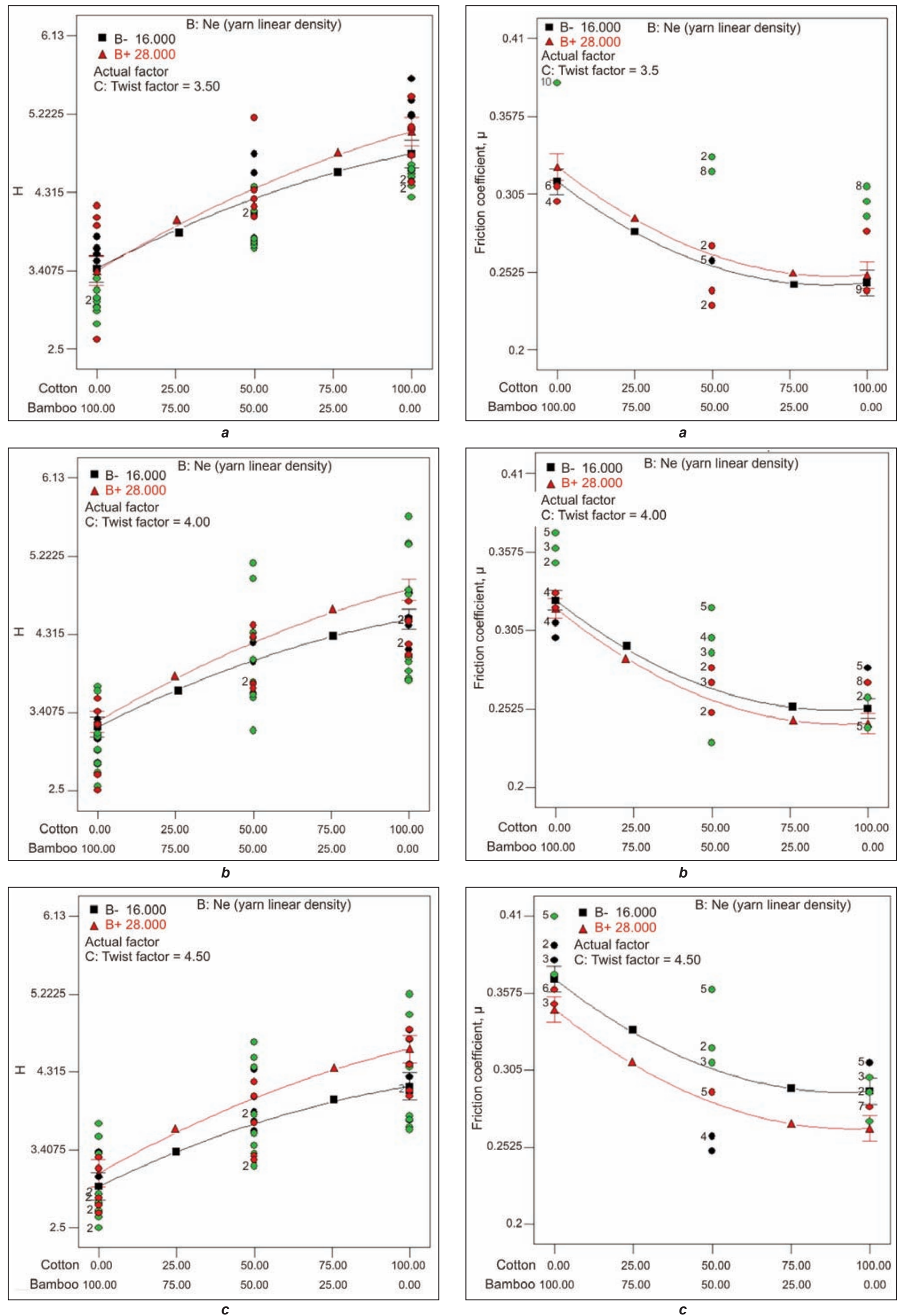

Fig. 4. Hairiness for cotton/bamboo blended yarns: $a-\alpha_{e}=3.5 ; b-\alpha_{e}=4.0 ; c-\alpha_{e}=4.5$

Fig. 5. Friction coefficient variation for cotton/bamboo blended yarns: $a-\alpha_{e}=3.5 ; b-\alpha_{e}=4.0 ; c-\alpha_{e}=4.5$ 
investigated by statistical analysis. For this purpose pure bamboo and cotton yarns and 50\%/50\% cotton/bamboo blended yarns produced in four different yarn linear densities and five different twist coefficients. The conclusions arised from the study may be drawn as follows:

1. Yarn linear density is the most effective factor on the unevenness $\left(C V_{m} \%\right) . C V_{m} \%$ is high in finer yarns ( $\mathrm{Ne} \mathrm{28)}$ for each twist levels since the low number of fibres in the cross section. Increased number of fibres in yarn cross section regulates the imperfections and unevenness regions on the yarn.

2. Since the fibre length variation in cotton fibres is higher than that of bamboo, pure cotton yarns demonstrate high $C V_{m} \%$ than that of pure bamboo yarns.

3. The optimum $C V_{m} \%$ value was seen between $40 \%$ cotton $-60 \%$ bamboo and $50 \%$ cotton $-50 \% 50$ bamboo blend.

4. Blend ratio is the most effective factor on the hairiness. The cohesion forces between fibres are low due to the low number of fibres in the cross section of finer yarns, hence the fibres tend to protrude from the yarn hairiness in fine yarns much more than coarse yarns

5. As the cotton blend ratio in the yarn increases, the hairiness also increases which can be related to the high length and fineness variation of cotton fibres compared to the bamboo fibres.

6. Minimum hairiness was seen in pure bamboo yarns. While increasing the twist, fibre-to-fibre cohesion forces will increase which help to hold the fibre in the yarn body.

7. Blend ratio is the most effective factor on the friction coefficient. The finer yarns show higher friction coefficient; whereas in figure $5, b$ and $c$, coarser yarns have higher friction coefficient values than finer yarns.

8. The critical twist coefficient is $\alpha_{e}=3.77$ in which the friction coefficient of finer and coarser yarns are almost equal.

9. Increasing cotton blend in the yarn decreases the friction coefficient. This may be due to the high friction coefficient of bamboo fibre.

As an overall conclusion, increasing cotton ratio in the yarn structure increases unevenness and hairiness, whereas decreases friction coefficient, in general. One of the most influential reasons may be due to the contact surface area between yarn with metal. The yarn-metal friction coefficient will increase with increasing the effective contact area of the yarn to metal, as expected. The one end of the hairs is free from the yarn and these fibres are not in full contact with metal. In addition, increased unevenness results in increased variation in the diameter of yarn, which results in the lack of contact of yarn with metal during the yarn passing through testing device. Thus increased hairiness and unevenness decreases friction coefficient. These results are in accordance with the research of Altas and Kadoğlu [14].

The results of this study may be beneficial for yarn producers for characterizing the bamboo/cotton blended yarns. It may also be useful for determining the wax content for the yarns for further applications such as knitting and weaving in order to prevent from rupture of yarns during the process.

Acknowledgement

Authors are thankful to Basyazicioglu Textile Co., Kayseri, Turkey for their supports.

\section{BIBLIOGRAPHY}

[1] Ozgen, B. New biodegradable fibres, yarn properties and their applications in textiles: a review, In: Industria Textila, 2012, vol. 63, no. 1, pp. 3-7.

[2] Prakash, C., Ramakrishnan, G. and Koushik,C.V. Effect of blend ratio on the quality characteristics of bamboo/ cotton blended ring spun yarn, In: Fibres\&Textiles in Eastern Europe, 2011, vol. 89, pp. 38-40.

[3] Sekerden, F. Investigation on the unevenness, tenacity and elongation properties of bamboo/cotton blended yarns, In: Fibres\&Textiles in Eastern Europe, 2011, vol. 86, pp. 26-29.

[4] Li, L., Yan, H.Q. Tensile properties of regenerated bamboo yarn, In: Fibres\&Textiles in Eastern Europe, 2012, vol. 20, no. 1, pp. 20-22.

[5] Majumdar, A., Mukhopadhyay, S., Yadav, R. and Mondal, A.K. Properties of ring-spun yarns made from cotton and regenerated bamboo fibres, In: Indian Journal of Fibre and Textile Research, 2011, vol. 36, no. 1, pp. 18-23.

[6] Erdumlu, N. and Ozipek, B. Investigation of regenerated bamboo fibre and yarn characteristics, In: Fibres\&Textiles in Eastern Europe, 2008, vol. 16, no. 4, 43-47.

[7] Koc, E. and Demiryurek, O. Predicting the tensile strength of polyester/viscose blended open-end rotor spun yarns using the artificial neural network and statistical models, In: Industria Textila, 2011, vol. 62, no. 2, pp. 81-87.

[8] Hussain, U. Bin Younis, F., Usman, F., Hussain, T. and Ahmed, F. Comfort and mechanical properties of polyester/ bamboo and polyester/cotton blended knitted fabric, In: Journal of Engineered Fibers and Fabrics, 2015, vol. 10, no. 2, pp. 61-69.

[9] He, F.S., Gao, C.H. and Ye, S.Y. Effect of bamboo fiber modification on tribological performance of brake composites, In: International Conference on Advances in Materials and Manufacturing Processes, Advances in Composites, Pts 1 and 2, 2011, vol. 150-151, pp. 1801-1805. 
[10] Kobayashi, S., Ishibashi, T. and Ishikawa, H. Wear and tensile characteristics of rubber-bamboo fiber composite material, In: High Performance Structures and Composites, 2002, vol. 4, pp. 167-174.

[11] Ma, Y.H., Shen, S.L., Tong, J., Ye, W., Yang, Y.Z. and Zhou, J. Effects of bamboo fibers on friction performance of friction materials, In: Journal Of Thermoplastic Composite Materials, 2013, vol. 26, no. 6, pp. 845-859.

[12] Kuhm, D., Bueno, M.A. and Knittel, D. Fabric friction behavior: study using capstan equation and introduction into a fabric transport simulator, In: Textile Research Journal, 2014, vol. 84, no. 10, pp. 1070-1083.

[13] Balci, G. and Sular, V. Friction property in yarns: importance and measurement methods. In: The Journal of Textiles and Engineers, 2009, vol. 73-74, pp. 6-15.

[14] Altas, S. and Kadoglu H. Yarn-to-yarn and yarn-to-metal friction in relation to some properties of yarns, In: The Journal of Textiles and Engineers, 2009, vol. 73-74, pp. 1-5.

[15] Kilic, G.B., Sular, V. Frictional properties of cotton-Tencel yarns spun in different spinning systems, In: Textile Research Journal, 2012, vol. 82, no. 8, pp. 755-765.

[16] Svetnickiene, V. Investigation of friction properties of yarns from natural fibres, In: Mechanika, 2009, vol. 1, pp. 73-77.

[17] Gurarda, A., Yukseltan, E., Kaplangiray, B.M. and Kanik, M. The effects of various lubricants on the friction properties of sewing threads, In: Textile Research Journal, 2013, vol. 83, no. 12, pp. 1273-1282.

[18] Ozçelik Kayseri, G. The frictional and lint shedding characteristics of regenerated cellulosic yarns, In: Industria Textila, 2014, vol. 65, no. 5, pp. 263-270.

[19] Dönmez Kretzschmar, S., Nasiou, T. UsterZweigle HL 400-Different applications of hairiness length classification, In: Application Report, 2011.

[20] Slater, K. Yarn evenness: A critical appreciation of recent developments, In: Textile Progress, The Textile Institute, Manchester, 1986, vol.14, no. 3/4, ISBN: 0-900739-85-1, pp.1-12.

[21] Uster, 2002. Tester-4 Application Handbook.
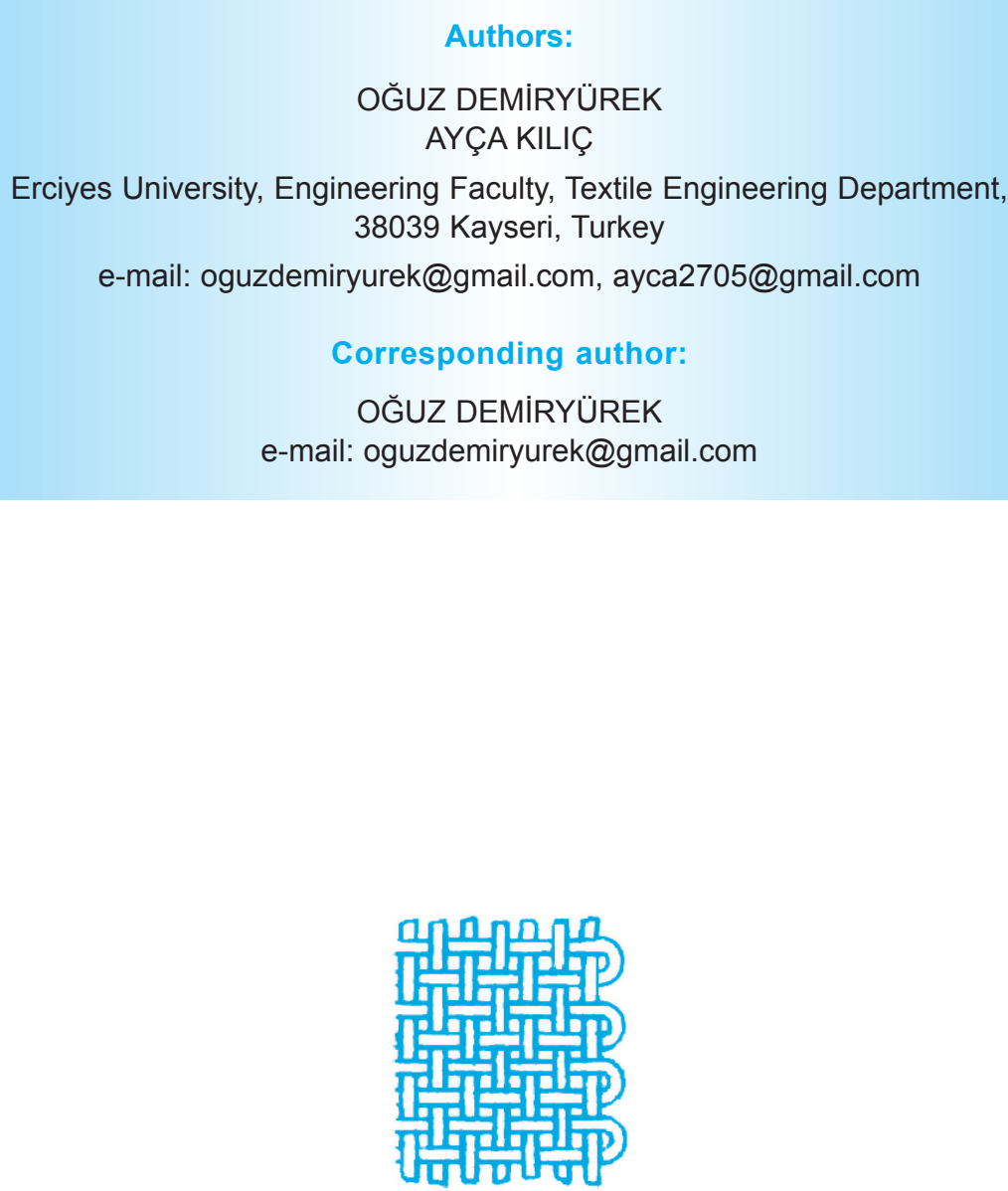